\title{
Analysis of the Relationship between Estradiol and Follicle-Stimulating Hormone Concentrations and Polymorphisms of Apolipoprotein E and LeptinGenes in Women Post-Menopause
}

\author{
Aleksandra Rył ${ }^{1}$, Andrzej Jasiewicz ${ }^{2}$, Anna Grzywacz ${ }^{2, *}$, Grażyna Adler ${ }^{3}$, \\ Karolina Skonieczna-Żydecka ${ }^{3}$, Iwona Rotter ${ }^{4}$, Olimpia Sipak-Szmigiel ${ }^{5}$, \\ Bogdan Rumianowski ${ }^{1}$, Beata Karakiewicz ${ }^{6}$, Anna Jurczak ${ }^{7}$, Miłosz Parczewski ${ }^{8}$, \\ Anna Urbańska ${ }^{8}$, Marta Grabowska ${ }^{1}$ and Maria Laszczyńska ${ }^{1}$ \\ 1 Department of Histology and Developmental Biology, Pomeranian Medical University, Szczecin 71-210, \\ Poland; ryl.ola@gmail.com (A.R.); bogdan.rumianowski@gmail.com (B.R.); \\ grabowska.marta.anna@gmail.com (M.G.); maria@laszczynska.pl (M.L.) \\ 2 Department of Psychiatry, Pomeranian Medical University, Szczecin 71-460, Poland; \\ andrzej.jasiewicz@gmail.com \\ 3 Department of Gerontobiology, Pomeranian Medical University, Szczecin 71-210, Poland; \\ gra2@op.pl (G.A.); karzyd@sci.pum.edu.pl (K.S.-Z.) \\ 4 Department of Rehabilitation Medicine, Pomeranian Medical University, Szczecin 71-210, Poland; \\ iwona.rotter@pum.edu.pl \\ 5 Department of Obstetric and Gynecological Nursing, Pomeranian Medical University, Szczecin 71-210, \\ Poland; olimpiasipak-szmigiel@wp.pl \\ 6 Department of Public Health, Pomeranian Medical University, Szczecin 71-210, Poland; \\ karabea@pum.edu.pl \\ 7 Department of Nursing, Pomeranian Medical University, Szczecin 71-210, Poland; jurczaka@op.pl \\ 8 Department of Infectious, Tropical Diseases and Immune Deficiency, Pomeranian Medical University, \\ Szczecin 71-455, Poland; milosz.parczewski@pum.edu.pl (M.P.); urbanska@pum.edu.pl (A.U.) \\ * Correspondence: annagrzywacz@gazeta.pl; Tel.: +48-914541507
}

Academic Editor: Paul B. Tchounwou

Received: 19 April 2016; Accepted: 25 May 2016; Published: 28 May 2016

\begin{abstract}
Background: Menopause is the permanent cessation of menstruation due to loss of ovarian follicular activity. A review of the available literature indicates that correlations between the changes that take place in a woman's body after menopause and different genetic variants are still being sought. Methods: The study was conducted in 252 women who had completed physiological menopause. The women were divided into groups according to the time elapsed since menopause. The total concentrations of estradiol and follicle-stimulating hormone were determined by means of electrochemiluminescence. The apolipoprotein $\mathrm{E}(A P O E)$ and lepitn (LEP) genotypes were determined by real-time PCR and polymerase chain reaction-restriction fragment length polymorphism, respectively. Results: We observed that people with the APOE3/E3 genotype entered menopause insignificantly later compared to other genotypes. Additionally, in the group of patients with the APOE3/E3 genotypes, differences in the E2 concentration were significantly related to the time since their last menstruation. There is no association found in the literature between these polymorphisms of the LEP gene and hormones. Conclusions: To date, attempts to formulate a model describing the association between E2 and FSH concentration with the polymorphisms of various genes of menopause in women have not been successful. This relationship is difficult to study because of the number of nongenetic factors. Environmental factors can explain variation in postmenopausal changes in hormone levels.
\end{abstract}


Keywords: menopause; hormones; apolipoprotein E; leptin

\section{Introduction}

According to the 1996 definition of the World Health Organization (WHO), menopause is the permanent cessation of menstruation due to loss of ovarian follicular activity [1,2]. Because of the substantial ontogenic diversity of women at the age when their menstruation disorders, climacteric symptoms, and the final menstruation occur, a system of uniform classification of hormonal, biological, and clinical changes called STRAW (Staging Reproductive Aging Workshops) was suggested in 2001 [3]. The time of final menstruation depends mainly on genetic [3-6] factors, but also on iatrogenic factors in cases where women have undergone chemotherapy, surgery, or radiation therapy of the ovarian region [6].

Estrogen deficiency results in the increased secretion of insulin by the pancreas, metabolic disorders, the development of obesity, and insulin resistance [7-11]. Our previous research studies have shown the presence of receptors for FSH and LH [12] as well as $\alpha$ estrogen receptors [13,14].

Leptin is a protein consisting of 167 amino acids that is coded by the LEP gene mapped on chromosome 7q31.3 $[15,16]$. The gene consists of three exons separated by two introns. The coding region is located in exons 2 and 3 [17]. Within the promoter region of this gene, a few sequences controlling its expression have been found [17]. Expression control occurs mainly in the cells of white adipose tissue, and its extent is dependent on the location of this tissue in the organism $[15,16]$. Numerous polymorphisms of the LEP gene and its receptor (coded by the LEPR gene) have been identified. One of the most commonly described polymorphisms of the $L E P$ gene is the substitution of cytosine (C) for adenine (A) at position -2548 within the promoter region, located above the ATG transcription start site [18]. It has been demonstrated that polymorphism $-2548 \mathrm{G}<\mathrm{A}$ is related to the risk of menopause, osteoporosis, and obesity, as well as cancer of the breast and endometrium [18,19].

Changes in particular hormonal actions occur after menopause, and have an impact on women's health and psychosocial life [20]. A gene of great importance to the development of neurovegetative changes in the brain is apolipoprotein $\mathrm{E}$ (APOE), located on chromosome 19 (region 19q13.2) [21,22].

Apolipoprotein $\mathrm{E}(A P O E)$ is a polymorphic protein with three isomorphic forms, including $A P O E 2, A P O E 3$, and APOE4, coded by three allelic arrangements of the APOE gene-namely, E2, E3, and $E 4[23,24]$. The most common allele in Caucasian women is the APOE3 allele, which is found in $78 \%$ of cases. The APOE 4 allele is found in $14 \%$ of the population, while the APOE2 allele occurs in $8 \%$ of the women covered by the previous study [25].

$A P O E$ is synthesized in a range of tissues, including the brain, liver, spleen, adrenal glands, and kidneys. The primary site of the APOE mRNA expression is the liver, secreting approximately $75 \%$ of this protein that circulates in blood plasma, with the brain being the second key secreting tissue [25]. The APOE4 isoform protects neurons from oxidative stress less actively, with a less efficient decrease in microglia and astroglia activation, and has been associated with severe inflammation [26,27]. The presence of the $A P O E 4$ allele has also been related to amyloid beta accumulation in the brain, which is of great importance in the pathogenesis of Alzheimer's disease [28,29]. Furthermore, the APOE3/E4 and $A P O E$ E4/E4 genotypes have been associated with better memorization. On the other hand, the $A P O E E 3 / E 3$ genotype is related to higher concentrations of prolactin and increased psychomotor speed [30]. It was found that polymorphic variants of the APOE gene can have an impact on hormones, including estrogen in the central nervous system [31].

A review of the current literature shows that correlations between the changes that take place in a woman's body after menopause and different genetic variants are still being sought. In particular, the literature contains few articles that directly address the relationship between the polymorphisms investigated here and menopause. The aim of this study was to examine the association between 
estradiol and follicle-stimulating hormone concentration with polymorphisms of $A P O E$ and $L E P$ genes in postmenopausal women.

\section{Materials and Methods}

The study was conducted in 252 women who had completed physiological menopause and who did not use menopausal hormone therapy. The mean age of the cohort was $59.1( \pm 6.4)$. The women were divided into three groups, according to the time that had elapsed since menopause. Groups A, B, and $C$ included women who were respectively $<5,6-10$, and over 10 years after menopause.

Patients with active and uncompensated hyperthyroidism, as well as an active alcohol dependency or active cancerous disease, were excluded from the study. Those patients who were being treated with antipsychotics, antidepressants, or steroids were also excluded from the study. Informed consent was obtained from all participating patients.

Venous blood was collected from the ulnar vein to determine hormonal and genetic parameters. Serum was stored in the freezer at $-20^{\circ} \mathrm{C}$.

\subsection{Determining Hormone Concentrations}

Estradiol (E2) and follicle-stimulating hormone (FSH) concentrations were determined from the blood serum. The total concentration of these hormones was determined by means of the electrochemiluminescence (ECLIA) method with monoclonal antibodies using a COBAS E411 (Roche Diagnostics, Poland) analyzer. The sensitivity limit for FSH was $0.10 \mathrm{mlU} / \mathrm{mL}$, while for E2 it was $5.0 \mathrm{pg} / \mathrm{mL}$.

\subsection{Data Collection}

Genomic DNA from peripheral blood leukocytes was extracted using a High Pure PCR Template Preparation extraction kit (Roche Diagnostics, Mannheim, Germany). The extraction was performed according to the manufacturer's instructions. The genetic investigation was carried out in a laboratory of the Department of Infectious Tropical Diseases at the Pomeranian Medical University, Szczecin, Poland. DNA samples were stored at $4{ }^{\circ} \mathrm{C}$ for further analysis.

\subsection{Genotyping of the Rs7799039 Mutation of the LEP Gene}

Analysis of the LEP-2548 G>A (rs7799039) polymorphism was carried out using polymerase chain reaction-restriction fragment length polymorphism (PCR-RFLP). The following primers were used: forward $5^{\prime}$-TTTCCTGTAATTTTCCCGTGA- $3^{\prime}$ and reverse $5^{\prime}$-AAAGCAAAGACAGGCATAAA- $3^{\prime}$. The PCR time and temperature profile were as follows: initial denaturation at $94{ }^{\circ} \mathrm{C}$ for $5 \mathrm{~min}$ then 38 cycles of denaturation at $94{ }^{\circ} \mathrm{C}$ for $20 \mathrm{~s}$, annealing at $54{ }^{\circ} \mathrm{C}$ for $40 \mathrm{~s}$, extension at $72{ }^{\circ} \mathrm{C}$ for $40 \mathrm{~s}$, and final extension at $72{ }^{\circ} \mathrm{C}$ for $8 \mathrm{~min}$. The 242 base pair (bp) amplicon was digested with 1 unit of $C f o I$ restriction enzyme for $24 \mathrm{~h}$ at $37^{\circ} \mathrm{C}$ and resolved on $3 \%$ agarose gel stained with GelStarTM (Lonza, Rockland, ME, USA) for visualization under UV light. Wild allele (-2548 G) was cleaved into 181 and $61 \mathrm{bp}$ restriction fragments, and the mutant one (-2548 A) remained unleaded. Random samples were genotyped twice, independently. All results were found to be reliable.

\subsection{Genotyping of the Rs429358 and Rs7412 Mutations of the APOE Gene}

Genotypes were determined by real-time PCR using the StepOne Real-Time PCR System (Applied Biosystems, Foster City, CA, USA) and TaqMan SNP Genotyping Assays for two APOE polymorphisms, including rs429358 and rs7412 (Life Technologies, Assay ID: C_3084793_20, C_904973_10, respectively; Foster City, CA, USA). The data were analyzed using Taq Man Genotyper Software v. 1.0.1 (Applied Biosystems, Foster City, CA, USA). 


\section{Statistical Analysis}

Data analysis was performed using SPSS Statistics v. 17.0 software (SPSS Inc., Chicago, IL, USA). Basic statistics included determination of group sizes, minima, maxima, arithmetic means, and standard deviations. The normality of the distributions was tested using a Shapiro-Wilk test. The quantitative data was analyzed using the Mann-Whitney $U$-test, Student's $t$-test, and the Kruskal-Wallis test, as well as ANOVA. Data measured on a dichotomous scale were analyzed using a chi-square test of independence with Yates' correction. The results were deemed significant at $p<0.05$.

\section{Permission to Conduct Research}

The study was approved by the Bioethics Committee of the Pomeranian University, Szczecin, with approval number BN-001/98/98.

\section{Results}

A total of 252 postmenopausal women (Table 1) were enrolled in the study and divided into three groups based on the time since their final menstruation: women up to 5 years post-menopause (Group A; $n=88$ ), women 6-10 years post-menopause (Group B; $n=81$ ), and women over 10 years post-menopause (Group C; $n=83$ ). The analysis of genotype frequencies (Table 2) showed that the most frequent polymorphic variant of the APOE gene was APOE3E3 $(70.45 \%$ in Group A, $77.78 \%$ in Group B, 69.88\% in Group C). In the case of polymorphism -2548 G>A of the LEP gene, the AG genotype was dominant (52.27\% in Group A, $48.15 \%$ in Group B, $60.24 \%$ in Group C).

By analyzing the groups (Table 3), it was observed that people with the APOE3/E3 genotype entered menopause insignificantly later than patients with the other genotypes. Additionally, in the group of patients with the APOE3E3 genotypes, differences in the E2 concentration were significantly related to the period of time since their final menstruation $(p=0.04)$. Among these patients, a higher concentration was observed in Group B than in Groups A and C. In women with different $A P O E$ genotypes, this relation was also not found $(p=0.23)$. While analyzing the influence of the APOE genotype on body mass index (BMI), the FSH concentration, and the age of first menstruation, statistical significances were not observed.

The analysis of the relation between the $-2548 \mathrm{G}>\mathrm{A} L E P$ polymorphism and the time of onset of menopause, BMI values, FSH and E2 concentrations, and first menstruation age did not show any significant differences. 
Table 1. Baseline characteristics of study participants.

\begin{tabular}{|c|c|c|c|c|c|c|c|c|c|c|c|c|}
\hline \multirow[t]{2}{*}{ Parameters } & \multicolumn{4}{|c|}{$\begin{array}{l}\text { Group A: Women up to } 5 \text { Years } \\
\text { Post-Menopause }(n=88)\end{array}$} & \multicolumn{4}{|c|}{$\begin{array}{l}\text { Group B: Women 5-10 Years } \\
\text { Post-Menopause }(n=81)\end{array}$} & \multicolumn{4}{|c|}{$\begin{array}{l}\text { Group C: Women 10-15 Years } \\
\text { Post-Menopause }(n=83)\end{array}$} \\
\hline & $\bar{X}$ & SD & Min & $\operatorname{Max}$ & $\bar{X}$ & SD & Min & Max & $\bar{X}$ & SD & Min & $\operatorname{Max}$ \\
\hline Age (years) & 54.8 & 3.6 & 47.0 & 63.0 & 57.5 & 4.2 & 41.0 & 67.0 & 65.2 & 6.0 & 53.0 & 78.0 \\
\hline Age of menopause (years) & 52.0 & 3.2 & 44.0 & 60.0 & 49.8 & 3.9 & 35.0 & 58.0 & 48.6 & 4.3 & 33.0 & 57.0 \\
\hline Last menstrual period (years) & 2.8 & 1.5 & 1.0 & 5.0 & 7.7 & 1.4 & 6.0 & 10.0 & 16.6 & 5.9 & 11.0 & 45.0 \\
\hline Height (m) & 1.6 & 0.1 & 1.5 & 1.7 & 1.6 & 0.1 & 1.5 & 1.7 & 1.6 & 0.1 & 1.5 & 1.7 \\
\hline Weight (kg) & 71.1 & 11.4 & 52.0 & 103.0 & 68.6 & 9.9 & 51.0 & 100.0 & 68.7 & 11.4 & 45.0 & 99.0 \\
\hline $\operatorname{BMI}\left(\mathrm{kg} / \mathrm{m}^{2}\right)$ & 27.4 & 4.4 & 21.1 & 39.45 & 26.3 & 3.8 & 20.5 & 37.6 & 26.4 & 4.0 & 18.0 & 36.8 \\
\hline FSH $(\mathrm{mIU} / \mathrm{mL})$ & 70.2 & 26.4 & 26.1 & 146.1 & 74.2 & 24.8 & 30.0 & 145.8 & 76.7 & 24.9 & 28.0 & 146.2 \\
\hline $\mathrm{E} 2(\mathrm{pg} / \mathrm{mL})$ & 9.0 & 5.7 & 5.0 & 21.3 & 7.6 & 5.1 & 5.0 & 23.4 & 7.7 & 4.8 & 5.0 & 19.4 \\
\hline Number of children born & 1.6 & 0.8 & 0 & 3 & 1.9 & 0.9 & 0 & 4 & 1.8 & 0.8 & 0 & 4 \\
\hline Age at first birth (years) & 24.2 & 3.9 & 18.0 & 38.0 & 23.6 & 3.0 & 18.0 & 34.0 & 24.1 & 3.4 & 19.0 & 36.0 \\
\hline Age of menarche (years) & 13.5 & 1.8 & 10.0 & 19.0 & 13.7 & 1.9 & 9.0 & 18.0 & 14.3 & 1.5 & 10.0 & 18.0 \\
\hline
\end{tabular}

BMI: body mass index; FSH: follicle-stimulating hormone; E2: estradiol; $\bar{X}$ : arithmetic mean; SD: standard deviation.

Table 2. Frequency of particular genotypes of the APOE and LEP genesin study groups.

\begin{tabular}{|c|c|c|c|c|c|c|c|}
\hline \multicolumn{2}{|c|}{ Genotypes } & \multicolumn{2}{|c|}{$\begin{array}{l}\text { Group A Women up to } 5 \text { Years } \\
\text { Post-Menopause }(n=88)\end{array}$} & \multicolumn{2}{|c|}{$\begin{array}{l}\text { Group B Women 5-10 Years } \\
\text { Post-Menopause }(n=81)\end{array}$} & \multicolumn{2}{|c|}{$\begin{array}{l}\text { Group C Women 10-15 Years } \\
\text { Post-Menopause }(n=83)\end{array}$} \\
\hline Gene & Genotype & Frequency & $\%$ of $n$ & Frequency & $\%$ of $n$ & Frequency & $\%$ of $n$ \\
\hline \multirow{6}{*}{$A P O E$} & E2E2 & 0 & 0.00 & 0 & 0.00 & 2 & 2.41 \\
\hline & E2E3 & 9 & 10.23 & 9 & 11.11 & 7 & 8.43 \\
\hline & $\mathrm{E} 2 \mathrm{E} 4$ & 0 & 0.00 & 2 & 2.47 & 1 & 1.20 \\
\hline & E3E3 & 62 & 70.45 & 63 & 77.78 & 58 & 69.88 \\
\hline & E3E4 & 16 & 18.18 & 7 & 8.64 & 13 & 15.66 \\
\hline & $\mathrm{E} 4 \mathrm{E} 4$ & 1 & 1.14 & 0 & 0.00 & 2 & 2.41 \\
\hline \multirow[b]{2}{*}{ APOE } & Other genotypes & 26 & 29.55 & 18 & 22.22 & 25 & 30.12 \\
\hline & E3E3 & 62 & 70.45 & 63 & 77.78 & 58 & 69.88 \\
\hline \multirow{3}{*}{ LEP } & AA & 13 & 14.77 & 13 & 16.05 & 12 & 14.46 \\
\hline & GA & 46 & 52.27 & 39 & 48.15 & 50 & 60.24 \\
\hline & GG & 29 & 32.95 & 29 & 35.80 & 21 & 25.30 \\
\hline \multirow{2}{*}{$L E P$} & Other genotypes & 42 & 47.73 & 42 & 51.85 & 33 & 39.76 \\
\hline & GA & 46 & 52.27 & 39 & 48.15 & 50 & 60.24 \\
\hline
\end{tabular}


Table 3. Statistical analysis of parameters in postmenopausal women, including polymorphic variant APOE.

\begin{tabular}{|c|c|c|c|c|c|c|c|c|c|c|c|c|}
\hline \multirow{2}{*}{$A P O E$} & \multirow{2}{*}{ Group } & \multicolumn{5}{|c|}{ Other Genotypes (E2E2, E2E3, E2E4, E3E4, E4E4) } & \multicolumn{5}{|c|}{ E3E3 } & \multirow{2}{*}{$p^{* *}$} \\
\hline & & $\bar{X}$ & SD & Min & Max & $p^{*}$ & $\bar{X}$ & SD & Min & Max & $p^{*}$ & \\
\hline \multirow{3}{*}{ Age of menopause (years) } & A & 51.3 & 3.6 & 46.0 & 58.0 & \multirow{3}{*}{$<0.01$} & 53.2 & 3.1 & 46.0 & 58.0 & \multirow{3}{*}{$<0.01$} & 0.70 \\
\hline & $\mathrm{B}$ & 48.5 & 2.4 & 45.0 & 52.0 & & 50.0 & 2.8 & 46.0 & 58.0 & & 0.46 \\
\hline & $\mathrm{C}$ & 49.0 & 3.3 & 42.0 & 53.0 & & 49.0 & 4.9 & 33.0 & 57.0 & & 0.76 \\
\hline \multirow{3}{*}{$\mathrm{BMI}\left(\mathrm{kg} / \mathrm{m}^{2}\right)$} & A & 27.4 & 4.5 & 22.3 & 36.4 & \multirow{3}{*}{0.91} & 26.5 & 4.0 & 21.3 & 37.5 & \multirow{3}{*}{0.31} & 0.82 \\
\hline & B & 27.2 & 5.4 & 22.9 & 37.6 & & 26.2 & 2.6 & 21.5 & 31.2 & & 0.72 \\
\hline & $\mathrm{C}$ & 27.2 & 4.4 & 22.0 & 33.9 & & 25.7 & 3.8 & 18.0 & 34.1 & & 0.72 \\
\hline \multirow{3}{*}{ FSH (mIU /mL) } & $\mathrm{A}$ & 58.4 & 18.5 & 26.2 & 94.1 & \multirow{3}{*}{0.16} & 66.0 & 24.5 & 28.0 & 124.6 & \multirow{3}{*}{0.75} & 0.22 \\
\hline & B & 64.3 & 19.6 & 35.8 & 91.4 & & 68.6 & 25.3 & 30.0 & 129.7 & & 0.79 \\
\hline & $\mathrm{C}$ & 75.2 & 32.5 & 37.2 & 140.9 & & 78.3 & 19.7 & 48.8 & 136.4 & & 0.55 \\
\hline \multirow{3}{*}{ E2 (pg/mL) } & $\mathrm{A}$ & 10.2 & 6.0 & 5.0 & 20.1 & \multirow{3}{*}{0.23} & 8.6 & 5.2 & 5.0 & 21.3 & \multirow{3}{*}{0.04} & 0.35 \\
\hline & B & 7.1 & 3.0 & 5.0 & 23.4 & & 7.5 & 5.7 & 5.0 & 23.3 & & 0.95 \\
\hline & $\mathrm{C}$ & 8.4 & 6.4 & 5.0 & 19.4 & & 5.9 & 3.9 & 5.0 & 15.1 & & 0.09 \\
\hline \multirow{3}{*}{ Age of menarche (years) } & A & 13.4 & 1.8 & 10.0 & 16.0 & \multirow{3}{*}{0.23} & 13.6 & 1.9 & 11.0 & 19.0 & \multirow{3}{*}{0.15} & 0.88 \\
\hline & B & 12.7 & 3.1 & 9.0 & 18.0 & & 14.0 & 1.4 & 11.0 & 16.0 & & 0.11 \\
\hline & C & 14.3 & 1.6 & 12.0 & 18.0 & & 14.3 & 1.5 & 10.0 & 17.0 & & 0.57 \\
\hline
\end{tabular}

Group A included women up to 5 years post-menopause, Group B included women 5-10 years post-menopause, and Group C included women over 10 years post-menopause $p^{*}$ : statistical significance between Groups 1,2 and 3 within the genotypes under study: $p^{* *}$ statistical significance between the E3E3 genotype and the remaining ennotypes in the ( 


\section{Discussion}

In the context of such a complex issue as the perimenopause in women, researchers have chosen a variety of genetic studies with which to identify the biological determinants of menopause. This is not an easy task, however, because menopause is multigenic and multifactorial. Nevertheless, researchers have reported their attempts to combine genetic variants with different aspects of menopausal syndromes [3,5,6,32]. We selected two genes in our study: one for APOE and one for $L E P$, on the basis of biological conditions mentioned in [33-38] to be associated with menopause.

In our study of the APOE gene (rs429358 and rs7412), in Groups A and C, a lower estradiol concentration was found in women with the E3E3 genotype than in the case of the other genotypes (E2E2, E2E3, E2E4, E3E4, E4E4). However, these results were not statistically significant. It should be noted that mean estradiol for each group is close to detection limit, which suggests that a substantial proportion of the study samples fall below the limit of the assay. The power analysis demonstrated that the power test was almost $20 \%(0.18)$. With age, the E3E3 genotype women are more prone to have a lower estradiol concentration than women with other genotypes in the polymorphism investigated here. When the age of the patients who took part in the study was considered, this relation was not observed. This is evidence that this relation is not directly dependent on the patient's age, but rather depends on the age when menopause occurred.

The APOE gene and its polymorphic variants investigated here are described in the literature primarily as genes predisposed to Alzheimer's disease. In the study of Yuan et al. [32], apolipoprotein $\mathrm{E}$ and oxidative damage were correlated with the risk of Alzheimer's. Those researchers found that plasma and erythrocyte antioxidant parameter levels were associated with APOE rs429358, rs7412 polymorphism. The influence of the APOE rs429358 polymorphism on plasma and erythrocyte antioxidant parameters could be modified by the GSTT1 genotype; the influence of APOE rs7412 could be modified by the GSTM1 (genes for the glutathione S-transferase family) genotype.

Both female sex [33] and the E4 variant of the APOE coding gene are among the most important and best-known risk factors in Alzheimer's [39]. Researchers have identified a protective effect of estrogens in the context of this disease's occurrence in women [34]. In our study, the estradiol concentration for the E2E2, E2E3, E2E4, E3E4, and E4E4 genotypes compared to E3E3 genotype was higher in the Group A and Group $C$ age ranges after menopause. However, it should be emphasized that the E3E3 genotype is very common, so this group has a larger sample size. Perhaps the "other genotypes" group might not show this significant difference because the sample size of this group is smaller. Furthermore, Lambrinoudaki et al. [35] observed in their pilot study that polymorphisms of $A P O E$ and paraoxonase 1 are associated with different levels of the thyroid hormone and anti-TG antibody levels in the study population. A statistically significant correlation was found between apolipoprotein E polymorphisms and serum thyroid hormones: carriers of the E2 or E4 allele of the $A P O E$ gene had lower levels of FT4 than women with the E3E3 genotype. A statistically significant positive association was also observed between anti-TG antibodies and the presence of the E2 allele of the APOE gene.

Apolipoprotein E [40,41] (APOE) is a 34-kDa protein that plays an important role in lipoprotein metabolism by association with lipoprotein particles and with members of the low-density lipoprotein (LDL) receptor family. It is known that there are three $A P O E$ isoforms (E2, E3, and E4), each of which have different affinities for their binding receptors. APOE2 has the defective characteristic of binding to low-density lipoprotein receptor (LDLR) through the cysteine at amino acid position 158, which affects the upregulation of the synthesis of 3-hydroxy-3-methylglutaryl coenzyme A (HMG-CoA) and LDLR and ultimately results in low serum LDL levels [42]. Lee D.J. et al. [36], in their study of APOE3, suggest that obesity or metabolic syndrome risk should be effectively managed in APOE3 isoform groups to reduce serum LDL in postmenopausal Korean women. In a different study, Issa et al. [37] found that menopause is associated with changes in lipid levels, resulting in an increased risk of atherosclerosis and cardiovascular events. They noticed that medication used to lower the level of 
cholesterol (Atorvastatin) downregulates the APOE mRNA expression and is modified by APOE genotypes in peripheral blood mononuclear cells from postmenopausal women.

A number of researchers have associated LEP and polymorphisms of its gene with changes that take place in physiological processes in women after menopause. Lee et al. [38] studied the following polymorphisms of the LEP gene in 592 postmenopausal Korean women: c.280 G>A, LEPR c.326 A >G, LEPR c.668 A>G, LEPR c.1968 G>C, LEPR c.2096 C>T, ADRB2 c.46 A>G, ADRB2 c.79 C>G, ADRB2 c.718 T>C, ADRB2 c.741 G>T, ADRB2 c.769 G>A, and ADRB3 c.190 T>C. Serum levels of leptin, soluble leptin receptor, osteoprotegerin, bone alkaline phosphatase, and carboxy-terminal of type I collagen were measured, and the bone mineral density at the lumbar spine and femoral neck were also examined. Among the polymorphisms measured, only LEPR c.1968 G>C was found to be associated with bone mineral density at the femoral neck, and higher BMI values were observed with an increasing number of $G$ alleles. Osteoporosis at the femoral neck was 3.27 and 3.89 times more frequently observed in the AG and GG genotypes than in the AA genotype with the ADRB2 c.46 $\mathrm{A}>\mathrm{G}$ polymorphism. However, no significant differences in serum levels of leptin, soluble leptin receptor, free leptin index, osteoprotegerin, or bone turnover markers were detected among single or haplotype genotypes.

There is no association found in the literature between the polymorphism of the LEP gene studied here and hormones in women after menopause. Our research study is thus pioneering in this respect. No associations with the LEP gene or its genotypic or allelic variants were observed in the groups under study.

\section{Conclusions}

To date, attempts to formulate a correct model of the association between E2 and FSH concentration with polymorphisms of various genes of menopause in women have not been successful. This relationship is difficult to study because of the number of nongenetic factors involved. Environmental factors can explain changes in hormone levels in postmenopausal women. Plans are therefore being made for further studies involving a larger group of patients.

Author Contributions: Aleksandra Rył, Andrzej Jasiewicz, Anna Grzywacz, Bogdan Rumianowski, and Maria Laszczyńska conceived and designed the experiments; Grażyna Adler, Karolina Skonieczna-Żydecka, Miłosz Parczewski, and Anna Urbańska performed the experiments; Aleksandra Rył, Andrzej Jasiewicz, Anna Grzywacz, Iwona Rotter, and Maria Laszczyńska analyzed the data; Beata Karakiewicz, Andrzej Jasiewicz, and Marta Grabowska contributed reagents; Aleksandra Rył, Anna Jurczak, Anna Grzywacz, and Bogdan Rumianowski contributed materials and analysis tools; Aleksandra Rył, Anna Grzywacz, Iwona Rotter, Olimpia Sipak-Szmigiel, and Maria Laszczyńska wrote the paper.

Conflicts of Interest: The authors declare no conflict of interest.

\section{References}

1. Izetbegovic, S.; Stojkanovic, G.; Ribic, N.; Mehmedbasic, E. Features of postmenopausal uterine haemorrhage. Med. Arch. 2013, 67, 431-434. [CrossRef] [PubMed]

2. Rumianowski, B.; Adler, G.; Safranow, K.; Brodowska, A.; Karakiewicz, B.; Słuczanowska-Głąbowska, S.; Łoniewska, B.; Piasecka, M.; Ciechanowicz, A.; Laszczyńska, M. CYP17 and CYP19 genetic variants are not associated with age at natural menopause in Polish women. Reprod. Biol. 2012, 12, 368-373. [CrossRef] [PubMed]

3. Soules, M.R.; Sherman, S.; Parrott, E.; Rebar, R.; Santoro, N.; Utian, W.; Woods, N. Executive summary: Stages of Reproductive Aging Workshop (STRAW). Fertil. Steril. 2001, 76, 874-878. [CrossRef]

4. Kaczmarek, M. The timing of natural menopause in Poland and associated factors. Maturitas 2007, 57, 139-153. [CrossRef] [PubMed]

5. Hefler, L.A.; Grimm, C.; Heinze, G.; Schneeberger, C.; Mueller, M.W.; Muendlein, A.; Huber, J.C.; Leodolter, S.; Tempfer, C.B. Estrogen-metabolizing gene polymorphisms and age at natural menopause in Caucasian women. Hum. Reprod. 2005, 20, 1422-1427. [CrossRef] [PubMed] 
6. He, L.N.; Xiong, D.H.; Liu, Y.J.; Zhang, F.; Recker, R.R.; Deng, H.W. Association study of the oestrogen signalling pathway genes in relation to age at natural menopause. J. Genet. 2007, 86, 269-276. [CrossRef] [PubMed]

7. Nippita, T.A.; Baber, R.J. Premature ovarian failure: A review. Climacteric 2007, 10, 11-22. [CrossRef] [PubMed]

8. Parker, W.H.; Broder, M.S.; Chang, E.; Feskanich, D.; Farquhar, C.; Liu, Z.; Shoupe, D.; Berek, J.S.; Hankinson, S.; Manson, J.E. Ovarian conservation at the time of hysterectomy and long-term health outcomes in the nurses' health study. Obstet. Gynecol. 2009, 113, 1027-1037. [CrossRef] [PubMed]

9. Montalcini, T.; Gorgone, G.; Gazzaruso, C.; Sesti, G.; Perticone, F.; Pujia, A. Endogenous testosterone and endothelial function in postmenopausal women. Coron. Artery Dis. 2007, 18, 9-13. [CrossRef] [PubMed]

10. Lobo, R.A. Surgical menopause and cardiovascular risks. Menopause 2007, 14, 562-566. [CrossRef] [PubMed]

11. Rumianowski, B.; Rotter, I.; Brodowska, A.; Adler, G.; Kowalski, J.; Karakiewicz, B.; Laszczyńska, M. Influence of Selected Reproductive Factors and Smoking on Age at Menopause. Gesundheitswesen 2015. [CrossRef]

12. Brodowska, A.; Laszczyńska, M.; Brodowski, J.; Masiuk, M.; Starczewski, A. Analysis of pituitary gonadotropin concentration in blood serum and immunolocalization and immunoexpression of follicle stimulating hormone and luteinising hormone receptors in ovaries of postmenopausal women. Histol. Histopathol. 2012, 27, 241-248. [PubMed]

13. Brodowska, A.; Laszczynska, M.; Starczewski, A.; Karakiewicz, B.; Brodowski, J. The localization of estrogen receptor alpha and its function in the ovaries of postmenopausal women. Folia Histochem. Cytobiol. 2007, 45, 325-330. [PubMed]

14. Brodowska, A.; Laszczyńska, M.; Starczewski, A.; Brodowski, J.; Masiuk, M.; Domagala, W. Immunohistochemical analysis of steroid receptors in ovaries of postmenopausal women-Effects of aging and hormone status. Histol. Histopathol. 2010, 25, 1009-1016. [PubMed]

15. Zhang, Y.; Proenca, R.; Maffei, M.; Barone, M.; Leopold, L.; Friedman, J. Positional cloning of the mouse obese gene and its human homologue. Nature 1994, 372, 425-432. [CrossRef] [PubMed]

16. Gorska, E.; Popko, K.; Ciepiela, O.; Kucharska, A.; Wasik, M. Leptin receptors. Eur. J. Med. Res. 2010, 2, $50-54$.

17. Ahima, S.R.; Flier, J.S. Leptin Annu. Rev. Physiol. 2000, 62, 413-437. [CrossRef] [PubMed]

18. Cleveland, R.J.; Gammon, M.D.; Long, C.M.; Gaudet, M.M.; Eng, S.M.; Teitelbaum, S.L.; Neugut, A.I.; Santella, R.M. Common genetic variations in the LEP and LEPR genes, obesity and breast cancer incidence and survival. Breast Cancer Res. Treat. 2010, 3, 745-752. [CrossRef] [PubMed]

19. Chovanec, J.; Bienertova-Vasku, J.A.; Dostalova, Z. Leptin-2548G/A polymorphism in endometria cancer. Klin. Onkol 2009, 22, 223-227. [PubMed]

20. Bojar, I.; Gustaw-Rothenberg, K.; Owoc, A. Cognitive impairment after menopause-The problem is still present. Przeglad. Menopauzalny. 2011, 10, 68-72.

21. Fillit, H.; Nash, D.T.; Rundek, T.; Zuckerman, A. Cardiovascular risk factors and dementia. Am. J. Geriatr. Pharmacother. 2008, 6, 100-118. [CrossRef] [PubMed]

22. Yaffe, K. Metabolic syndrome and congenitive disorders: is the sum greater than its parts? Alzheimer Dis. Assoc. Disord. 2007, 21, 167-171. [CrossRef] [PubMed]

23. Dickstein, D.L.; Walsh, J.; Brautigam, H.; Stockton, S.D., Jr.; Gandy, S.; Hof, P.R. Role of vascular risk factors and vascular dysfunction in Alzheimer's disease. Mt. Sinai J. Med. 2010, 77, 82-102. [CrossRef] [PubMed]

24. Wright, C.B.; Festa, J.R.; Paik, M.C.; Schmiedigen, A.; Brown, T.R.; Yoshita, M.; DeCarli, C.; Sacco, R.; Stern, Y. White matter hyperintensities and subclinical infarction: Associations with psychomotor speed and congenitive flexibility. Strocke 2008, 39, 800-805. [CrossRef] [PubMed]

25. Laws, S.M.; Hone, E.; Gandy, S.; Martins, R.N. Expanding the association between the APOE gene and the risk of Alzheimer's disease: possible roles for APOE promoter polymorphisms and alterations in APOE transcription. J. Neurochem. 2003, 84, 1215-1236. [CrossRef] [PubMed]

26. Scarmeas, N.; Stern, Y.; Mayeux, R.; Manly, J.J.; Schupf, N.; Luchsinger, J.A. Mediterranean diet and mild cognitive impairment. Arch. Neurol. 2009, 66, 216-225. [CrossRef] [PubMed]

27. Scarmeas, N.; Luchsinger, J.A.; Stern, Y.; Gu, Y.; He, J.; DeCarli, C.; Brown, T.; Brickman, A.M. Mediterranean diet and magnetic resonance imaging-assessed cerebrovascular disease. Ann. Neurol. 2011, 69, 257-268. [CrossRef] [PubMed] 
28. Jiang, Q.; Lee, C.Y.; Mandrekar, S.; Wilkinson, B.; Cramer, P.; Zelcer, N.; Mann, K.; Lamb, B.; Willson, T.M.; Collins, J.L.; et al. APOE promotes the proteolytic degradation of Abeta. Neuron 2008, 58, 681-693. [CrossRef] [PubMed]

29. Arbones-Mainar, J.M.; Johnson, L.A.; Altenburg, M.K.; Maeda, N. Differential modulation of diet-induced obesity and adipocyte functionality by human apolipoprotein E3 and E4 in mice. Int. J. Obes. (Lond.) 2008, 32, 1595-1605. [CrossRef] [PubMed]

30. Bojar, I.; Raczkiewicz, D.; Wdowiak, A.; Owoc, A. The effect of prolactin and apolipoprotein E gene polymorphism on cognitive functions of menopausal women. Ginekol. Pol. 2014, 85, 131-139. [CrossRef] [PubMed]

31. Nathan, B.P.; Barsukova, A.G.; Shen, F.; McAsey, M.; Struble, R.G. Estrogen facilitates neurite extension via apolipoprotein E in cultured adult mouse cortical neurons. Endocrinology 2004, 145, 3065-3073. [CrossRef] [PubMed]

32. Yuan, L.; Liu, J.; Dong, L.; Cai, C.; Wang, S.; Wang, B.; Xiao, R. Effects of APOE rs429358, rs7412 and GSTM1/GSTT1 Polymorphism on Plasma and Erythrocyte Antioxidant Parameters and Cognition in Old Chinese Adults. Nutrients. 2015, 24, 8261-8273. [CrossRef] [PubMed]

33. Di Carlo, A.; Baldereschi, M.; Amaducci, L.; Lepore, V.; Bracco, L.; Maggi, S.; Bonaiuto, S.; Perissinotto, E.; Scarlato, G.; Farchi, G.; Inzitari, D.; ILSA Working Group. Incidence of dementia, Alzheimer's disease, and vascular dementia in Italy. The ILSA Study. J. Am. Geriatr. Soc. 2002, 50, 41-48. [CrossRef] [PubMed]

34. Paganini-Hill, A.; Henderson, V.W. Estrogen deficiency and risk of Alzheimer's disease in women. Am. J. Epidemiol. 1994, 140, 256-261. [PubMed]

35. Lambrinoudaki, I.; Kaparos, G.; Rizos, D.; Galapi, F.; Alexandrou, A.; Sergentanis, T.N.; Creatsa, M.; Christodoulakos, G.; Kouskouni, E.; Botsis, D. Apolipoprotein E and Paraoxonase 1 polymorphisms are associated with lower serum thyroid hormones in postmenopausal women. Clin. Endocrinol. (Oxf.) 2009, 71, 284-290. [CrossRef] [PubMed]

36. Lee, D.J.; Kim, K.M.; Kim, B.T.; Kim, K.N.; Joo, N.S. APOE polymorphism may determine low-density lipoprotein cholesterol level in association with obesity and metabolic syndrome in postmenopausal Korean women. Yonsei. Med. J. 2011, 52, 429-234. [CrossRef] [PubMed]

37. Issa, M.H.; Cerda, A.; Genvigir, F.D.; Cavalli, S.A.; Bertolami, M.C.; Faludi, A.A.; Hirata, M.H.; Hirata, R.D. Atorvastatin and hormone therapy effects on APOE mRNA expression in hypercholesterolemic postmenopausal women. J. Steroid Biochem. Mol. Biol. 2012, 128, 139-144. [CrossRef] [PubMed]

38. Lee, H.J.; Kim, H.; Ku, S.Y.; Choi, Y.M.; Kim, J.H.; Kim, J.G. Association between polymorphisms in leptin, leptin receptor, and $\beta$-adrenergic receptor genes and bone mineral density in postmenopausal Korean women. Menopause 2014, 21, 67-73. [CrossRef] [PubMed]

39. Sadigh-Eteghad, S.; Talebi, M.; Farhoudi, M. Association of Apolipoprotein E epsilon 4 allele with sporadic late onset Alzheimer's disease. A meta-analysis. Neurosciences (Riyadh) 2012, 17, 321-326. [PubMed]

40. Ruiz, J.; Kouiavskaia, D.; Migliorini, M.; Robinson, S.; Saenko, E.L.; Gorlatova, N.; Li, D.; Lawrence, D.; Hyman, B.T.; Weisgraberm, K.H.; et al. The APOE isoform binding properties of the VLDL receptor reveal marked differences from LRP and the LDL receptor. J. Lipid Res. 2005, 46, 1721-1731. [CrossRef] [PubMed]

41. Weisgraber, K.H. Apolipoprotein E: Structure-function relationships. Adv. Protein Chem. 1994, 45, $249-302$. [PubMed]

42. Mahley, R.W. Apolipoprotein E: Cholesterol transport protein with expanding role in cell biology. Science 1988, 240, 622-630. [CrossRef] [PubMed]

(C) 2016 by the authors; licensee MDPI, Basel, Switzerland. This article is an open access article distributed under the terms and conditions of the Creative Commons Attribution (CC-BY) license (http://creativecommons.org/licenses/by/4.0/). 